\title{
Research from rubble
}

\author{
University returns to work in makeshift lecture halls and laboratories.
}

\section{L'AQUILA, ITALY}

Amid the rubble of the University of L'Aquila, Italy, which was mostly destroyed by a magnitude- 6.3 earthquake on 6 April, a Nobelprizewinning biologist arrived last week to offer his support. To a packed marquee, Robert Horvitz tried to restore a semblance of normalcy by lecturing about his work on programmed cell death.

"It was a question of showing scientific solidarity with people who live in a community that has suffered losses on so many levels," says Horvitz, of the Massachusetts Institute of Technology in Cambridge. "They've lost life, homes - and also a perspective on how they can return to normality."

Fifty-five students were among the 295 people who died in the quake, which shattered the town and its neighbouring villages, and destroyed much of the university.

Six weeks later, with $70 \%$ of its staff homeless, the 23,000-student university is starting to work again - in tents or in buildings loaned by other towns. The underground particle-physics laboratory at Gran Sasso, which remained undamaged 15 kilometres from L'Aquila, resumed work on 4 May, even though $90 \%$ of its staff are homeless.

Researchers are worried about being forgotten by the outside world, or abandoned by their students, during the rebuilding process - which is expected to take many years. To help to avert a drain of human capital, the Italian government has promised to maintain a constant budget for the university, at $€ 68.5$ million (US\$92 million) annually for three years, and to reduce student fees. It is also giving $€ 70$ million for rebuilding. Prime minister Silvio Berlusconi has also transferred July's G8 meeting from the island of La Maddalena to L'Aquila, to bring in external money for building, although some fear that it could prove to be a disruption.

To try to maintain meaningful international connections, the science faculty - about 465 of 600 academics - is offering the town of L'Aquila as an 'open laboratory' for the testing of new scientific ideas during reconstruction. "The university needs to be involved in the rebuilding of an ancient city with modern technologies and modern ideas," says Paola Inverardi, dean of science, who is living in a tent in her sister's garden. "The tragedy can also be an opportunity."

More than 1,300 scientists have indicated their interest in being involved on the 'Ideas for L'Aquila' webpage (www.ideasforlaquila.org). Ideas being discussed include a consortium for 'adaptive music', which would incorporate music that adjusts to a changing environment in the infrastructure of the restored city.

Inverardi, a computer scientist, says that collaborations forged with international partners could help the university to emerge from the disaster in better intellectual shape than before.

But the road to recovery is very steep. Only two buildings on the university's two out-oftown campuses remain structurally sound and will be habitable within a few months. The rest are substantially damaged - as is the entirety of the humanities faculty and university administration located in the historic centre. The centre is still a no-go area, a dusty, rubble-strewn ghost town brightened only by red fire engines. The yellow stuccoed university rectory seems to lean, crumbling into a narrow alley already choked with fallen bricks.

Each department has had to find its own interim solution for teaching, which began again a couple of weeks ago. Some classes are taking place in the sea of blue tents erected by

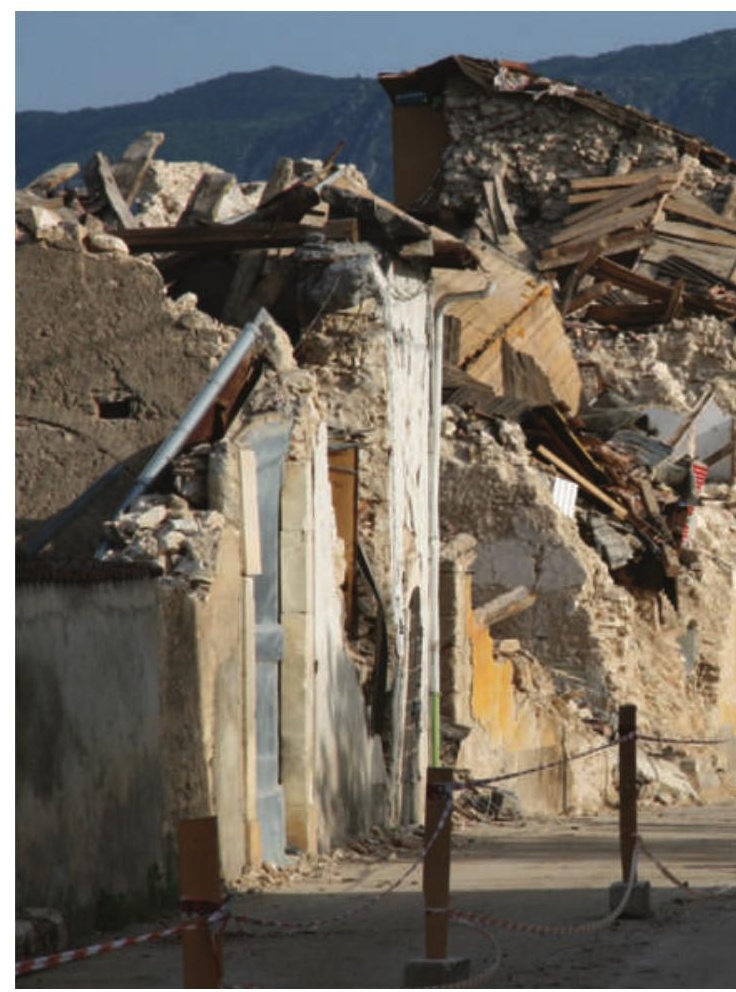

The historic centre of L'Aquila remains off-limits.

the civil-protection service on campus, or in larger marquees that have also hosted exams $\underset{\Sigma}{\Sigma}$ and academic ceremonies - as well as the seminars of Horvitz and his wife, neurobiologist Martha Constantine-Paton.

The physics faculty found a relatively easy solution by moving into the above-ground facilities of the Gran Sasso laboratories, where many homeless staff also sleep. "Of course there will be crowding - and it will be for some years," says Gran Sasso director Eugenio Coccia. "But we are glad to be able to have such a role."

It has not been easy to find the mental energy to think about science in the circumstances, admits Gran Sasso physicist Francesco Arneodo. "With so many homeless it is hard to focus your full attention on research," he says,

\section{Radon 'prediction' of earthquake rattles local scientists.}

"There are always people who say they had predicted every earthquake," says Tom Jordan, director of the Southern California Earthquake Center in Los Angeles. But the city of L'Aquila, Italy, had a particularly troublesome claimant this spring in amateur seismologist Giampaolo Giuliani.

After an earthquake devastated the town on 6 April, the international media covered
Giuliani's lament that Italian authorities had ignored his prediction of a big quake centred on Sulmona, a town some 60 kilometres away, at the end of March. Giuliani, a technician, had been tracking radon emission from the ground with a device he had patented.

Jordan has been invited by the Italian government to head an international committee of experts to analyse local seismic data - and, in part, to put to rest public concern that lives could have been saved by heeding predictions. Radon is indeed emitted from Earth during seismic activity, he says, but it is not useful in predicting earthquakes.

Giuliani's claim offended professional geologists such as Gianluca Ferrini of the University of L'Aquila, who had been monitoring the mounting seismic activity for several months. "We knew that the epicentre of what we were recording was getting deeper and stronger, so we knew there was a possibility of a big earthquake," he says. Ferrini and his colleagues had been giving survival advice in schools. If people had been evacuated from Sulmona to L'Aquila in response to an inaccurate prediction, he points out, many more people would have died. A.A. 
